\title{
NEW GLOSSOPTERID POLYSPERMS FROM THE PERMIAN LA GOLONDRINA FORMATION (SANTA CRUZ PROVINCE, ARGENTINA): POTENTIAL AFFINITIES AND BIOSTRATIGRAPHIC IMPLICATIONS
}

\author{
BÁRBARA CARIGLINO \\ Museo Argentino de Ciencias Naturales "Bernardino Rivadavia", CONICET, Av. Ángel Gallardo 470, C1405DJR, \\ Buenos Aires, Argentina. barichi10@gmail.com
}

\begin{abstract}
Impression fossils of ovuliferous fructifications from the Permian La Golondrina Formation in Santa Cruz, Argentina, are described, their affinities compared, and finally, assigned to the Arberiaceae (Glossopteridales). Based on morphological differences from the genera in Arberiaceae, a new taxon is established for some specimens, whereas others are allocated to Arberia madagascariensis (Appert) Anderson \& Anderson. This is the first record of Arberiaceae from the La Golondrina Basin. The biostratigraphic implications of the occurrence of this family in this unit are discussed, and suggest that more evidence other than that provided by the megafloral elements is needed to resolve the age of the constituent members of the La Golondrina Formation.
\end{abstract}

Key words: Arberiaceae, Argentina, biostratigraphy, fructifications, Glossopteridales, Gondwana.

RESUMO - São descritos impressões fósseis de frutificações femininas provenientes da Formação La Golondrina, Permiano de Santa Cruz (Argentina), atribuídas a Arberiaceae (Glossopteridales), segundo a comparação de suas afinidades. Com base nas diferenças morfológicas dos gêneros da Família Arberiaceae, um novo táxon é proposto, enquanto as outras amostras são alocadas em Arberia madagascariensis (Appert) Anderson \& Anderson. Este é o primeiro registro de Arberiaceae na bacia do La Golondrina. As implicações bioestratigráficas fornecidas pela presença deste grupo, nesta unidade, são discutidas e sugere-se que mais provas, além das fornecidas pelos elementos megaflorísticos, são necessárias para restringir os limites de idade do membro da Formação La Golondrina.

Palavras-chave: Arberiaceae, Argentina, bioestratigrafia, frutificações, Glossopteridales, Gondwana.

\section{INTRODUCTION}

During the second half of the last century and in recent years, a large number of interesting fructifications from the Glossopteris floras across Gondwana has come to light, revealing varied morphologies that imply great diversity amongst glossopterids and their associates. Key studies include those from India (Surange \& Chandra, 1975; Banerjee, 1984; Bajpai, 2001; Tewari et al., 2012; Srivastava \& Agnihotri, 2013), Australia (Holmes, 1974; Rigby, 1972, 1978; McLoughlin, 1990a,b, 1995, 2012a,b), South Africa (Anderson \& Anderson, 1985; Adendorff et al., 2002; Prevec et al., 2008; Prevec, 2011), Antarctica (Ryberg et al., 2012), and South America (Menéndez, 1962; Bernardes de Oliveira \& Carvalho, 1981; Bernardes de Oliveira et al., 2000; Rösler et al., 1994; Barreda \& Césari, 1995; Iannuzzi, 2010).

The taphoflora from the La Golondrina Formation (Santa Cruz Province, Argentina) is acknowledged as one of the most diverse Permian floras from South America. Fertile remains of glossopterids and sphenopsids and some plants of unknown affinities (Archangelsky, 1960, 1992; Archangelsky \& Bonetti, 1963; Cariglino et al., 2009; Cariglino, 2013; Carrizo \& Archangelsky, 2013) have enhanced understanding of the floristic diversity of the region. Despite the recent discoveries, fertile parts of other plant groups, for example lycopsids and cordaitaleans, have remained elusive in this unit.

This paper aims to describe three fructifications hitherto unknown from the La Golondrina Formation. Based on their general structure, the fructifications are compared with those of the Cordaitanthales (Cordaithanthus), Peltaspermales (Autunia), and Glossopteridales (Arberia, Rigbya), and their systematic position is clarified. Last, the biostratigraphic implications of these discoveries are also analyzed.

\section{MATERIAL AND METHODS}

The fossil specimens were recovered from the middle member of the La Golondrina Formation (Laguna Polina Member), at the Laguna Polina locality (La Golondrina Basin), Santa Cruz Province, Argentina (Figure 1). Stratigraphic and sedimentological descriptions of the area were detailed previously (Jalfin, 1987, 1990; Panza, 1994; Archangelsky et al., 1996a,b; Archangelsky, 2006; Gutiérrez et al., 2006), whereas several other works have documented the floral composition in all three members of this unit (Archangelsky, 1959; Arrondo, 1972; Cariglino, 2011, among others). 


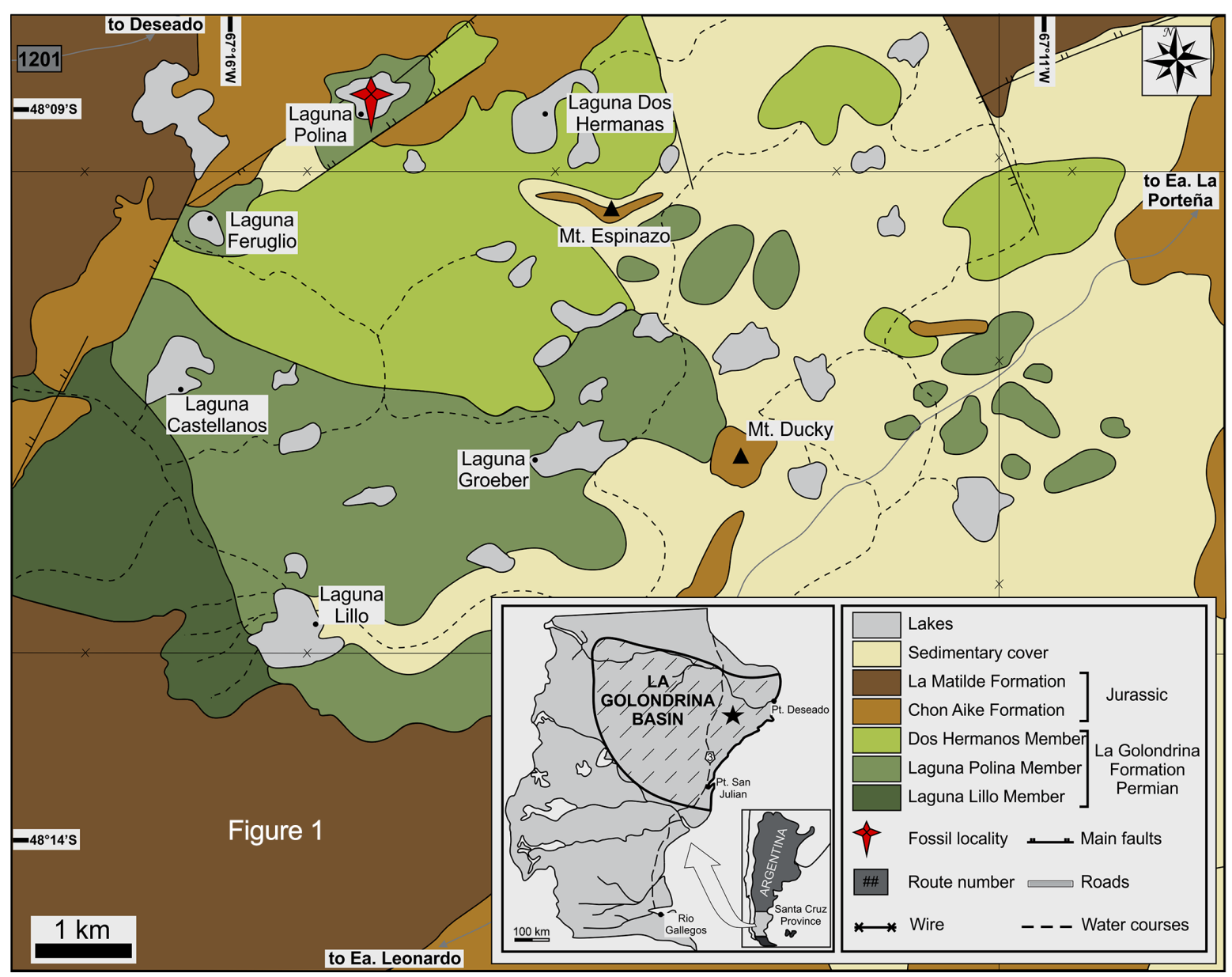

Figure 1. Geological map of the area from where the fossils were recovered.

The specimens described here consist of regular to well-preserved, in some cases fragmented impressions lacking their counterparts; consequently, neither detailed studies of their anatomy or cuticular analyses were possible. Specimens LIL Pb 1975 and LIL Pb 1381 were collected from the Laguna Polina Member by Dr. S. Archangelsky in 1957, and generously ceded to the author for this study. Specimen MPM Pb 4856 on the other hand, was collected on a field trip in 2010 from the same fossiliferous unit by the author. Abundant glossopterids (Gangamopteris spp., Glossopteris spp.), ferns (Asterotheca spp., Dizeugotheca spp., Dichotomopteris spp., Damudopteris sp.), sphenophytes (Sphenophyllum spp., Annularia sp., Phyllotheca sp.) and various other fructifications (Dictyopteridium spp., Plumsteadia spp., Eretmonia sp., ?Senotheca sp., cf. Lilpopia sp.), in addition to other less common elements (Cordaites sp, lycophytes, and coniferophytes), are also contained in the Laguna Polina Member (Archangelsky, 1959; Cariglino, 2011, 2013). On the basis of the assemblage in all three members, the La Golondrina Formation is considered to range in age from the latest Cisuralian (Laguna Lillo Member), the Guadalupian (Laguna Polina Member), to the Lopingian (Dos Hermanos Member).

The material was photographed using a Canon Powershot S5IS (8.0 megapixel) digital camera. For detailed analysis and illustration, specimens were photographed under strong unilateral light at different angles to enhance their surface relief using a Nikon DS-Fi1-U2 digital camera attached to a Nikon SMZ800 stereomicroscope. Measurement of specimens was done with a vernier caliper and using the scale tool in Adobe Photoshop CS3 on digital images. Images were only corrected for contrast.

Fossils under the prefix LIL Pb are housed at the Fundación Lillo paleobotany collection in Tucumán Province, whereas those with the MPM Pb prefix belong to the Museo Regional Provincial "Padre Jesús Molina" paleobotany collection, in Santa Cruz province.

\section{SYSTEMATIC PALAEOBOTANY}

Order GLOSSOPTERIDALES Pant, 1982
Family ARBERIACEAE Rigby, 1972

Golondrinia gen. nov.

Type species. Golondrinia archangelskyi sp. nov.; monotypic.

Stratigraphic and geographic range. Guadalupian?Lopingian of the La Golondrina Formation (Laguna Polina Member), Santa Cruz Province, Argentina. 
Etymology. In reference to the name of the estancia hosting the fossil localities (La Golondrina; also name of the basin and geological formation).

Generic diagnosis. Ovuliferous fructifications with a pinnate branching pattern comprising a primary axis bearing two lateral rows of opposite to sub-opposite pairs of branchlets at $90^{\circ}$ to the main axis. Main axis robust, stalked, and longitudinally striated. Branchlets short, stalked, finely striated, and expanded distally, ending as a flabelliform scalelike or cup-shaped structure. Ovule scars located on the fertile surface of the scales.

\section{Golondrinia archangelskyi sp. nov.}

(Figures 2A-G, 3, 4A-C)

Holotype. LIL Pb 1975 (Figures 2A-G, 3).

Paratype. MPM Pb 4856 (Figures 4A-C).

Type locality. Laguna Polina, Estancia La Golondrina, Santa Cruz Province, Argentina.

Type horizon. Laguna Polina Member.
Etymology. Dedicated to the Argentinian paleobotanist Dr. Sergio Archangelsky, for his pioneering work at the La Golondrina Formation.

Species diagnosis. Polysperm stalked, with a robust primary axis at least $85 \mathrm{~mm}$ long and $4.5 \mathrm{~mm}$ wide. Main axis with thick longitudinal striate. Lateral branching is pinnate. Branchlets are short $(<5 \mathrm{~mm})$, and finely striated; they attach to the main axis at about $90^{\circ}$ by a short stalk, and expand distally as a flabelliform scale-like feature that sometimes takes the shape of a cup. Scale features bifacial, with a single ovule attachment on the fertile surface and a striate sterile surface.

Description. The Golondrinia archangelskyi gen. et sp. nov. holotype (LIL Pb 1975; Figures 2A-G) is a well-preserved impression of an ovuliferous fructification. Its primary axis is $\sim 85 \mathrm{~mm}$ long (top is missing) and varies in thickness from $4.7 \mathrm{~mm}$ at the base to $2.0 \mathrm{~mm}$ at the top; although the broad basal part may represent a preservational artifact. The axis is longitudinally striate, with a maximum width, taking into account the lateral branchlets, of $\sim 8.0 \mathrm{~mm}$. More than 16 pairs (in some cases unpaired due to preservational issues) of
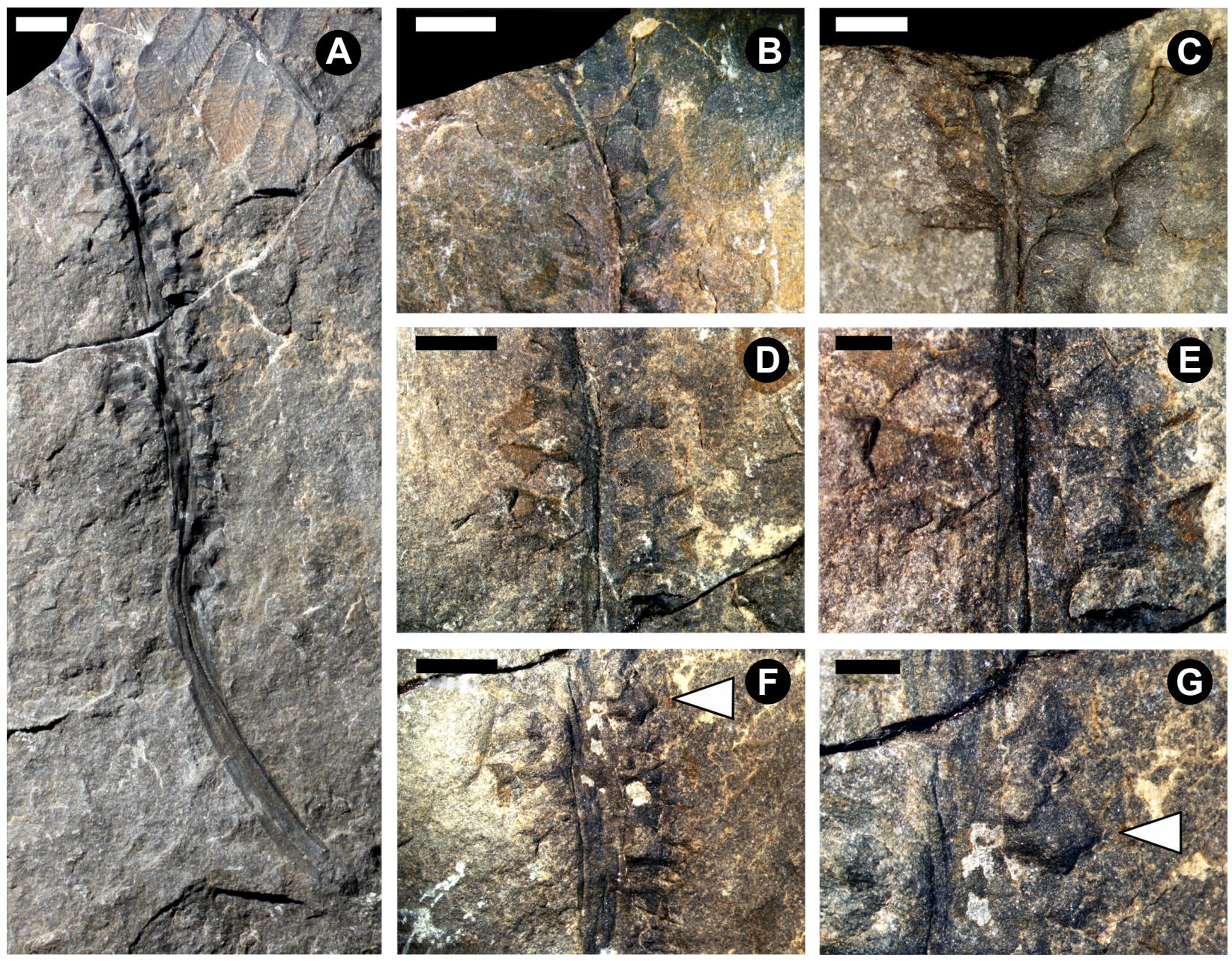

Figure 2. Holotype of Golondrinia archangeslkyi gen. et sp. nov. (LIL Pb 1975), recovered from the Laguna Polina Member, La Golondrina Formation, Permian of Santa Cruz, Argentina. A, preserved specimen; note stalked base; B-C, upper part of specimen, showing longitudinal striation of the main axis and finely striated fertile branchlets; D-E, middle part of specimen, showing different morphologies of fertile branchlets, sometimes ending in a scale-like structure, in other cases, as a cup-shaped feature; F-G, basal part of specimen, showing striated axis, fertile branchlets, and potential terminal ovule (arrow). 
striated branchlets are present, separated from each other by 2.0-2.2 $\mathrm{mm}$. Branchlets range from 4.3 to $4.9 \mathrm{~mm}$ long, and expand terminally, in some cases as a flabelliform feature, in other cases as an apparent cup-shaped structure (Figures 2D-E). Ovules were not seen directly, but could be inferred in some cases based on the rounded imprint (seed scar) on the fertile surface of the scales in some of the branchlets (Figures 2F-G; arrow).

The paratype (MPM Pb 4856; Figures 4A-C) is regularly preserved and less complete than LIL Pb 1975. The main axis is robust, at least $44 \mathrm{~mm}$ long (fragmented at the base and top) and $3.4 \mathrm{~mm}$ thick, reaching up to $10.1 \mathrm{~mm}$ when including a pair of branchlets. Axis is densely striate longitudinally (Figure 4A). More than 10 pairs of branchlets are present, each separated by $2.0 \mathrm{~mm}$, except at the apex, where they appear clustered (preservational artifact?) (Figure 4B). Branchlets are finely striated, with flabellate termini. Although questionable, faint imprints of solitary oval ovule scars $\sim 2.65 \mathrm{~mm}$ long and $1.6 \mathrm{~mm}$ wide are located on the surface of the scales in some branchlets on the lower right side of the main axis (Figure 4C; arrows).

Remarks. The features present in Golondrinia archangelskyi gen. et sp. nov. seem to combine a mixture of characters represented in Rigbyaceae and Arberiaceae. As previously mentioned, these specimens have an unbranched axis bearing two lateral rows of fertile branchlets. The axis is longitudinally striate, relatively long $(>40 \mathrm{~mm})$ and varies in thickness, slightly attenuating at the top. All these characteristics relate these specimens with Arberiaceae. On the other hand, the holotype of Golondrinia is basally complete (Figure 2A), showing that these fructifications were stalked, a character shared with both Rigbyaceae and Arberiaceae. Both studied specimens (LIL Pb 1975 and MPM Pb 4856) are referred to the same species based on the presence of an unbranched striated axis, and the two lateral rows of opposite to sub-opposite
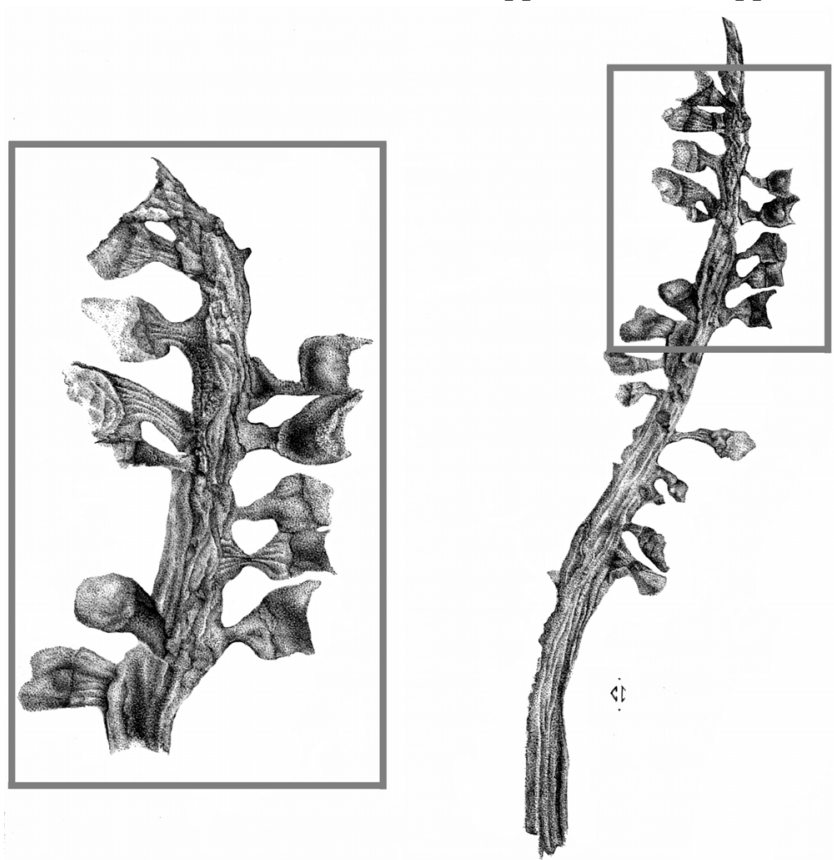

Figure 3. Hand illustration of Golondrinia archangelskyi gen. et sp. nov. holotype (LIL Pb 1975). Credits: Carmen Castellano. branchlets comprising a short, striated and in some cases, slightly expanded base, ending in a flabelliform, scale-like structure that is also longitudinally striate.

Arberia White, 1908

Type species. Arberia minasica White, 1908 emend. Rigby, 1972

\author{
Arberia madagascariensis (Appert) \\ Anderson \& Anderson, 1985
}

(Figures 5A-E)

Specimen number. LIL Pb 1381.

Stratigraphic and geographic range. Early Permian, Gondwana.

Description. Two similar, well-preserved impressions of fructifications are adjacent to each other, partially overlapping, but with no obvious organic connection between them or with the underlying Glossopteris retifera Feistmantel leaf (Figure 5A). One of the fructifications is $\sim 35 \mathrm{~mm}$ long (incomplete at the top) and $10 \mathrm{~mm}$ wide (maximum width); the other - upside-down in reference to the former - is 22 $\mathrm{mm}$ long and $7 \mathrm{~mm}$ wide (the base and apex are lacking). The primary axis is laminar and longitudinally striated; it expands slightly towards the apex and tapers to the base. Forking of the main axis is not evident from the preserved parts. The branching is pinnate; branches arise at varying degrees from the margins $\left(30^{\circ}\right.$ to $\left.>90^{\circ}\right)$, and are separated by $1.52-[2.41]-3.72 \mathrm{~mm}$ (more separated in the basal section, $\mathrm{N}=7$ ) from each other. The lateral branches are 3.56-[4.46]-5.4 $\mathrm{mm}$ long and $\sim 2.0 \mathrm{~mm}$ wide $(\mathrm{N}=6)$, and bear a conspicuous striae. These branches do not fork, and terminate in a simple scale-like expansion (Figures 5B-E). A small (1.76 mm long and $1.12 \mathrm{~mm}$ wide) platyspermic ovate seed with a narrow wing is closely associated with the base of one of the lateral branches in one of the specimens, and potentially pertains to the described polysperms (Figure 5D, arrow).

Remarks. The two polysperms in LIL Pb 1381 differ from Golondrinia archangelskyi gen. et sp. nov. by possessing flattened main axes that taper basally. Nevertheless, they share the longitudinal striation and the presence of two lateral rows of fertile branchlets, arising at varying degrees from the axis. Branchlets are also striated, and end in a simple scale-like expansion, as is the case in Golondrinia specimens. Ovule scars, and even a closely associated (if not in direct organic connection with) platyspermic seed, are observed at the base of some of the branchlets, adding stronger support for an affinity of LIL Pb 1381 with Arberiaceae (although platyspermic seeds are also associated with Rigbyaceae, see Schopf, 1976).

\section{DISCUSSION}

\section{Potential affinities}

Fructifications with a basic structural organization consisting of a main axis bearing two or more rows of fertile structures have evolved independently in several plant 

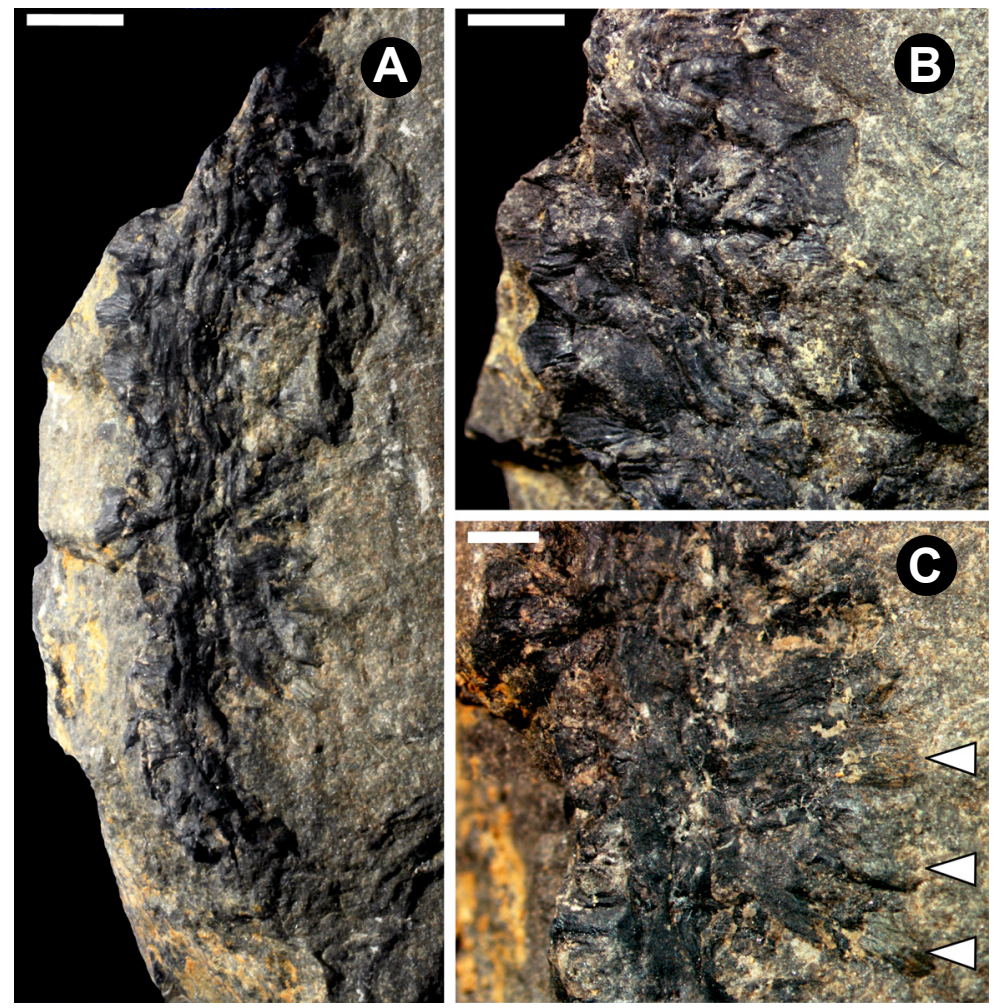

Figure 4. Paratype of Golondrinia archangelskyi gen. et sp. nov. (MPM Pb 4856) recovered from the Laguna Polina Member, La Golondrina Formation, Permian of Santa Cruz, Argentina. A, preserved specimen; B, upper part of specimen, showing the finely striated branchlets ending in a scalelike structure; $\mathbf{C}$, middle part of specimen, showing longitudinal striation of main axis and fertile branchlets with potential terminal ovules (arrows).
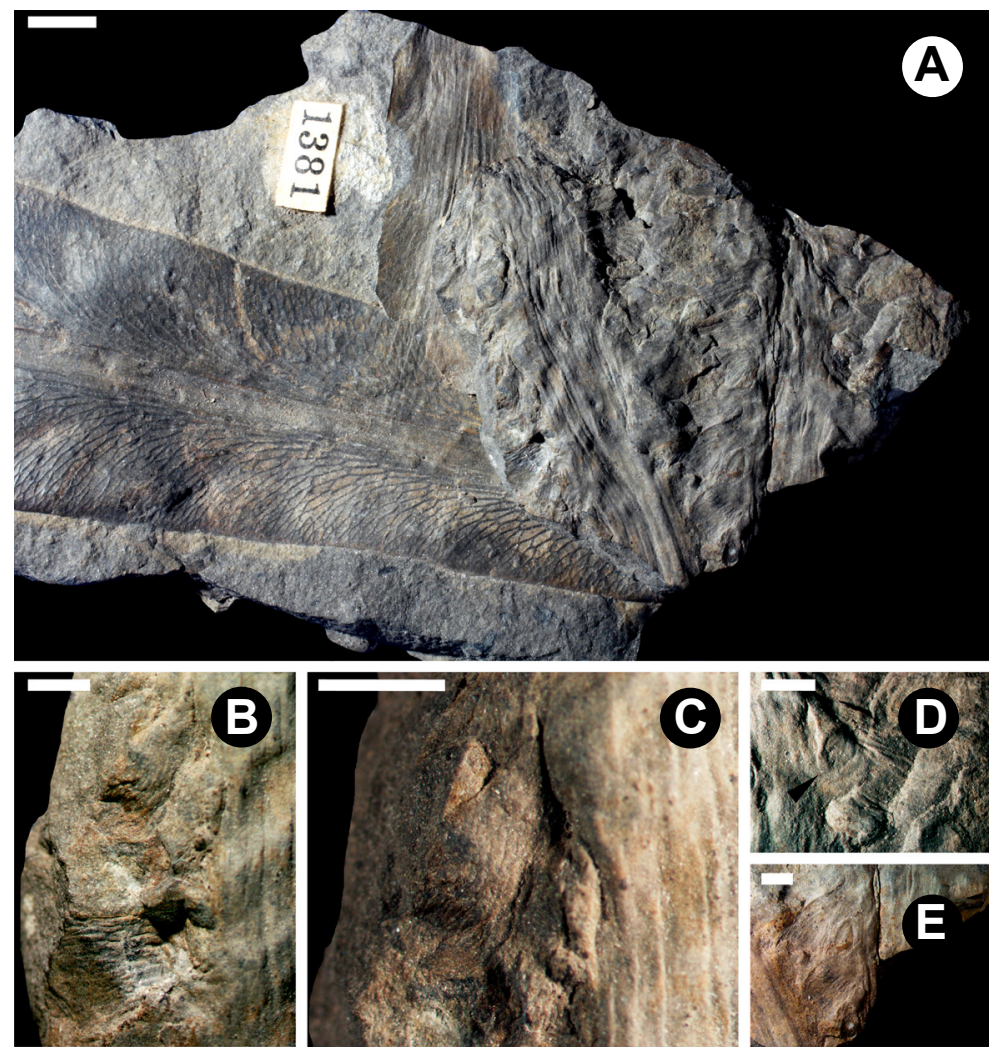

Figure 5. Arberia madagascariensis (LIL Pb 1381) recovered from the Laguna Polina Member, La Golondrina Formation, Permian of Santa Cruz, Argentina. A, two preserved specimens; the one on the right is upside-down; B, fertile branchlets, one showing ovule/seed scar at the base of the scale-like feature; C, fine striation of fertile branchlet; D, detail of fertile branchlet with platyspermic seed (arrow); $\mathbf{E}$, flabelliform, scale-like ends and striation of fertile branchlets. 
lineages. There is a wide variety of female reproductive structures that repeat this general morphology, and have been described using generic terms such as "cupules", "capsules", "cones", "megasporophylls" and "strobili". Although these terms do not necessarily imply homologies between the different forms, all are characterized by being used to describe ovule/seed-bearing structures. Some of the morphological characters exhibited in the fructifications from the La Golondrina are shared with plant taxa from the Cordaitanthales (Meyen, 1984), Peltaspermales (Delevoryas, 1979), and Glossopteridales (Pant, 1982). A discussion of the similarities and differences among them, and the potential affinities of the new material is given below. In order to narrow the comparisons, primary focus was placed on late Paleozoic floras, in particular with those that share elements with the paleoflora of the La Golondrina Formation.

Cordaitanthus-type fructifications from Gondwana were unknown until recently, when Césari \& Hünicken (2013) described fructifications associated with Cordaites bifolius, and assigned them to Cordaitanthus sp. 1 and 2. All other known Cordaitanthus species are from Carboniferous and Permian floras of the Northern Hemisphere (Feistmantel, 1876; Grand'Eury, 1877; Florin, 1951; Meyen, 1984; Rothwell, 1977, 1982, among many others). Meyen (1984) and Ignatiev \& Meyen (1989) pointed out the problematic use of Cordaitanthus as a genus, given it comprised both male and ovuliferous fructifications, disregarding differences in preservational types and quality. Among the many characters that were used by different authors to describe ovuliferous Cordaitanthus, it is possible to find various interpretations of these fructifications, including descriptions as a long, unbranched primary axis, bearing two lateral rows of opposite to alternate seeds either in the axils of bracts (i.e. Grand'Eury, 1877), on short pedicels composed by two or more sterile scales (Florin, 1951), or even sessile on the axis (Lesquereux, 1880), pointing out the problematic nature (or at least uncertain diagnostic limits) of this genus. At first impression, the presence of an unbranched primary axis, bearing two lateral rows of branchlets (= "secondary shoots") may fit under the wide definition of ovuliferous Cordaitanthus, especially if the branchlets in Golondrinia archangelskyi gen. et sp. nov. are considered as some sort of bract-axillary complex, since some of the cup-shaped termini on specimen LIL Pb 1975 could be interpreted as ovuliferous and subtending bracts (Figures 2D-E). Recently, a new taxonomic approach has been taken to define Cordaitanthus as a genus, including only compressions/impressions of either male or female lax cones, composed of a primary axis (cone axis), bearing distichous bracts and, in the axil of each bract, a secondary shoot with helically arranged scales that carry distally attached ovules or pollen cones (Ignatiev \& Meyen, 1989; Taylor et al., 2009). Thus, upon closer inspection, the gross similarities with the La Golondrina specimens disappear; even if there is a main axis with "secondary fertile shoots", these do not bear bracts or cones that reveal any affinity with the Cordaitanthales.
Golondrinia archangelskyi gen. et sp. nov. is also comparable to Permian peltasperms described from China and Russia (Wang, 1997; Naugolnykh \& Oskolski, 2010). The Autunia shanxiensis Wang specimens illustrated from the Permian of China (Wang, 1997, text-figs. 8a-c and e, text-figs. 9a-d) share certain resemblance in their overall morphology: a main striated axis with "megasporophylls" attached at right angles by a slender petiole, terminally ending in a broadly flabelliform head. However, from the species diagnosis, important differences arise: the megasporophylls are spirally attached to the main axis, forming a lax cone, and they are composed of a semi-rounded head with two or more flattened ovules of the Carpolithus-type (Kerp, 1988; Wang, 1997; Geng \& Hilton, 1999). Similar features are evident in the Peltaspermum species illustrated by Naugolnykh \& Oskolski (2010, figs. 1a,c), where they depict two impression fossils of fructifications comprising a main axis bearing two lateral rows of "racemose aggregation of seed-bearing discs" (Naugolnykh \& Oskolski, 2010, p. 30). The basic arrangement of these polysperms shows some features in common with the specimens from the La Golondrina Formation; however, Peltaspermum species are characterized by the presence of peltate discs attached to a main axis, whereas there are no peltate discs in the La Golondrina specimens.

Two ovuliferous fructifications of glossopteridean affinity from India and Africa share similar morphological features with Golondrinia archangelskyi gen. et sp. nov. Khania dhenkanalensis Chandra \& Singh is an ovuliferous fructification consisting of an unbranched, slender main axis, bearing two opposite rows of small stalks carrying seeds marked with vertical grooves (Chandra \& Singh, 1988), being the main difference with the specimen from the La Golondrina Formation the absence of a scale-like feature at the end of the branchlets. Wankiea bondii Lacey \& Huard-Moine is described as a seedbearing fructification with a longitudinally striated main axis bearing two orders of pinnately arranged branches, the ultimate order of branches forming clusters of 4-6 branchlets bearing ovate seed-like bodies. Although Lacey \& Huard-Moine (1966) indicated that the seed attachment was unclear, they suggested that seeds were possibly borne on a peltate expansion or a scale-like extension. Golondrinia archangelskyi gen. et sp. nov. shares with Wankieae bondii the basic arrangement of a main axis with pinnate branching and the seed attachment on a scale-like feature, although they differ in that in the former, there is only one order of branching.

All three fructifications described in this paper share most features with those of the Glossopteridales. More specifically, strong similarities are evident with fructifications from Arberiaceae and Rigbyaceae. Rigbyaceae polysperms have, in most cases, a long, slender stalk with short, dichotomous branchlets arranged into a flabellate lamina with varying degrees of fusion. Each branchlet bears a single ovule/seed, and ends in a scale-like structure that is longitudinally striate (Adendorff, 2005). Arberiaceae, on the other hand, have polysperms with a main axis, that may be unbranched or branched several times; the last order of branches bearing a single ovule/seed, and terminating in a distal scale-like 
structure, similar to those of Rigbyaceae (Rigby, 1972; Adendorff, 2005), but Arberiaceae polysperms do not have a fan-shaped primary axis. Taking into account the general architecture discussed above, both forms are attributed to Arberiaceae.

Golondrinia archangelskyi gen. et sp. nov. presents characteristics that fit well under the Family Arberiaceae (sensu Rigby, 1972, and as proposed to be emended by Adendorff, 2005), as it is an ovuliferous fructification comprising a longitudinally striated main axis with two lateral rows of fertile branchlets ending in an expanded scale-like structure. The creation of a new genus and species is justified by the morphological differences the specimens from the La Golondrina reveal with the four known architectural groupings attributed to Arberiaceae, viz., Arberia White emend. Rigby, 1972, Dolianitia Millan, 1967, 'Arberia' leeukuilensis Anderson \& Anderson, 1985 and Arberiopsis Bernardes de Oliveira, 1978 (Table 1). Dolianitia and Arberia are polysperms with a planar primary axis that is usually dichotomously branched, in some cases in multiple planes, characterized by "stocky striate pleiochasial axes with short ultimate branchlets bearing relatively large ovules" (Millan, 1967; McLoughlin, 1995, p. 183). The close similarities between Dolianitia and Arberia led several authors to consider them synonymous (Rigby, 1972; Banerjee, 1984; Anderson \& Anderson, 1985; McLoughlin, 1993, 1995). 'Arberia' leeukuilensis on the other hand, has a planated axis without dichotomies, bearing two opposite rows of ovuliferous, short, unspecialized branchlets "with rounded, pendulous, slightly expanded and strongly recurved termini" (see Adendorff, 2005, unpubl.). Thus, both 'Arberia' leeukuilensis and Golondrinia lack the dichotomous branching typical of Arberia and Dolianitia species. In addition, 'Arberia' leeukuilensis shares with Golondrinia a pinnate branching pattern on an undivided axis, but they differ in that the former has an axis that is planated and oblanceolate to narrowly elliptical, whereas in Golondrinia it is more akin to a slender axis. They also differ in that the fertile branchlets in 'Arberia' leeukuilensis are rounded, slightly expanded, and distally recurved, whereas in Golondrinia archangelskyi they have a short, striate base that expands distally, normally as a flabelliform feature. Although in neither of these genera the ovules were found attached, it is more likely these were borne on the fertile surface of the scale-like feature in Golondrinia, as inferred from the faint imprints of the ovule seed scars. Last, Arberiopsis is characterized by a slender rachis that

Table 1. Main morphological features and distribution of Arberiaceae taxa. 1, this work; 2, Maithy (1970); 3, Rigby (1972); 4, Chandra \& Srivastava (1981); 5, Surange \& Lele (1956); 6, McLoughlin (1995); 7, Adendorff (2005); 8, Anderson \& Anderson (1985); 9, Bernardes de Oliveira (1978). Abbreviations: EPm, Early Permian; MPm, Middle Permian.

\begin{tabular}{|c|c|c|c|c|c|}
\hline Taxon & Rachis/branching morphology & Ovule placement & Formation (Locality) & Age & Refs. \\
\hline $\begin{array}{l}\text { Golondrinia archangeslkyi } \\
\text { gen. et sp. nov. }\end{array}$ & $\begin{array}{l}\text { Undivided main axis, pinnate } \\
\text { branching, branchlets straight }\end{array}$ & $\begin{array}{l}\text { Ovules attached at the end of } \\
\text { each branchlet }\end{array}$ & $\begin{array}{l}\text { La Golondrina Fm. } \\
\text { (Argentina) }\end{array}$ & $\begin{array}{l}\text { Late EPm } \\
\text { (?)-MPm }\end{array}$ & 1 \\
\hline $\begin{array}{l}\text { Dolianitia (Arberia) } \\
\text { kaharbariensis Maithy }\end{array}$ & $\begin{array}{l}\text { Striated main axis, multi- } \\
\text { dichotomous irregular branching }\end{array}$ & unknown & Karharbari Fm. (India) & EPm & 2 \\
\hline $\begin{array}{l}\text { Arberia minasica White } \\
\text { emend. Rigby }\end{array}$ & $\begin{array}{l}\text { Thick striated rachis, pinnate or } \\
\text { dichotomous branching, very } \\
\text { variable }\end{array}$ & $\begin{array}{l}\text { Ovules inserted on expanded } \\
\text { cushions }\end{array}$ & $\begin{array}{l}\text { Rio Bonito Fm. (Brazil), } \\
\text { Arroyo Totoral Fm. } \\
\text { (Argentina) }\end{array}$ & EPm & 3 \\
\hline Arberia indica Feistmantel & $\begin{array}{l}\text { Flattened main rachis, } \\
\text { pinnate branching }\end{array}$ & Ovules on flattened tips & Karharbari Fm. (India) & EPm & 4 \\
\hline $\begin{array}{l}\text { Arberia surangei Chandra } \\
\& \text { Srivastava }\end{array}$ & $\begin{array}{l}\text { Flattened main rachis, } \\
\text { dichotomous branching }\end{array}$ & $\begin{array}{l}\text { Ovules attached on the apex } \\
\text { of each branchlet }\end{array}$ & Karharbari Fm. (India) & EPm & 4 \\
\hline $\begin{array}{l}\text { Arberia umbellata Surange } \\
\& \text { Lele }\end{array}$ & $\begin{array}{l}\text { Flattened main rachis, } \\
\text { dichotomous branching }\end{array}$ & $\begin{array}{l}\text { Ovules attached on recurved } \\
\text { branches }\end{array}$ & Talchir Fm. (India) & $\mathrm{EPm}$ & 5 \\
\hline $\begin{array}{l}\text { Arberia woolagaensis } \\
\text { McLoughlin }\end{array}$ & $\begin{array}{l}\text { Flattened, striated main rachis, } \\
\text { tappers basally, unbranched }\end{array}$ & $\begin{array}{l}\text { Ovules sessile or inserted on } \\
\text { short stalks along the margin } \\
\text { of rachis }\end{array}$ & $\begin{array}{l}\text { Irwin River Coal } \\
\text { Measures (Australia) }\end{array}$ & $\mathrm{EPm}$ & 6 \\
\hline $\begin{array}{l}\text { Arberia hlobanensis Anderson } \\
\& \text { Anderson emend. Adendorff }\end{array}$ & $\begin{array}{l}\text { Main axis with single major } \\
\text { dichotomy, branching } \\
\text { in multiple planes }\end{array}$ & $\begin{array}{l}1-2 \text { ovule attachments at the } \\
\text { base of the scale-like feature }\end{array}$ & $\begin{array}{l}\text { Vryheid Fm. (South } \\
\text { Africa) }\end{array}$ & EPm & 7,8 \\
\hline $\begin{array}{l}\text { Arberia madagascariensis } \\
\text { (Appert) emend. Adendorff }\end{array}$ & $\begin{array}{l}\text { Flattened, striated main rachis, } \\
\text { pinnate branching }\end{array}$ & $\begin{array}{l}\text { Ovules attachment at the base } \\
\text { of the scale-like feature }\end{array}$ & $\begin{array}{l}\text { Madagascar, South } \\
\text { Africa, } \\
\text { La Golondrina Fm. } \\
\text { (Argentina) }\end{array}$ & $\begin{array}{l}\mathrm{EPm} / \text { Late } \\
\mathrm{EPm}(?)- \\
\mathrm{MPm}\end{array}$ & 1,7 \\
\hline $\begin{array}{l}\text { 'Arberia' leeukuilensis And. } \\
\& \text { And. (see Adendorff, 2005) }\end{array}$ & $\begin{array}{l}\text { Flattened, striated main rachis, } \\
\text { pinnate branching with recurved } \\
\text { branchlets }\end{array}$ & $\begin{array}{l}\text { Rounded, barely expanded } \\
\text { seed attachment points }\end{array}$ & $\begin{array}{l}\text { Vryheid Fm. (South } \\
\text { Africa) }\end{array}$ & $\mathrm{EPm}$ & 7,8 \\
\hline $\begin{array}{l}\text { Arberiopsis boureaui } \\
\text { Bernardes de Oliveira }\end{array}$ & $\begin{array}{l}\text { Flattened, striated main axis, with } \\
\text { slightly anistomous branching in } \\
\text { a plane }\end{array}$ & $\begin{array}{l}\text { Ovules attached terminally to } \\
\text { last order branches }\end{array}$ & Rio Bonito Fm (Brazil) & $\mathrm{EPm}$ & 9 \\
\hline
\end{tabular}


dichotomizes various times in a slightly anistomous way, the branches of the last order bearing anatropous ovules. The primary difference with Golondrinia is, once again, that the main axis in the latter is not dichotomized.

Both specimens preserved on LIL $\mathrm{Pb} 1381$ are assigned to Arberia madagascariensis since they exhibit many of the diagnostic characters of the species. On contrary to the specimens described as Golondrinia archangelskyi gen. et sp. nov., the ovules (as indicated by the seed scars) in A. madagascariensis are placed at the base of the scales (Figures 5B, D).

The detailed description of Arberia madagascariensis provided by Adendorff (2005) and mostly based on the material from Madagascar originally described by Appert (1977), shares almost every qualitative feature with the specimens in LIL Pb 1381. The thorough emended generic and species diagnosis provided by Adendorff (2005) however, mentioned that the main axes are "commonly" bifurcated at the apex. Given that the specimens from the La Golondrina Formation (as well as the Madagascan examples) are apically incomplete, it is not possible to assess this feature. Nevertheless, it is important to point out that some Arberia species lack of an apical dichotomy (A. surangei, Chandra $\&$ Srivastava, 1981), thus the possibility of these specimens not having a dichotomized main axis is feasible; although I consider it unlikely, since all the most complete Arberia madagascariensis specimens found (South Africa) exhibit an apical bifurcation. Also, the South African and Madagascan specimens described by Adendorff (2005) are comparatively larger than the specimens from the La Golondrina. The presence of a platyspermic seed organically attached and figured in one of Appert's (1977) specimens is also seen in one of the two fructifications on LIL Pb 1381, where a seed is closely associated (or in direct contact) with the base of one lateral branchlet (Figure 4D); however, they differ in size, the latter being smaller. These differences in size could be explained as distinct growth stages; perhaps the La Golondrina specimens represent a less mature stage. Or the environmental conditions in which these plants grew were different, causing reduced growth. Regardless these few differences from the South African and Madagascan forms, the features of the specimens in LIL $\mathrm{Pb} 1381$ allow the confident allocation to A. madagascariensis.

Thus far, Arberia madagascariensis has been found only in Madagascar and South Africa. The new records extend the range of this species to South America. Other Arberia species are known from India, South Africa, Australia, Brazil and Argentina (Table 1). Arberia minasica (White) emend. Rigby, 1972, and Dolianitia (=Arberia) karharbarensis Pant \& Nautiyal, 1965 differ from $A$. madagascariensis in their multi-dichotomous branching. Arberia umbellata Surange \& Lele, 1956, and A. surangei Chandra \& Srivastava, 1981 differ from A. madagascariensis in having a more widespread apical region from which fertile branches dichotomize one or more times. The obovate primary axis in Arberia surangei, however, does not show the typical apical dichotomy, similar to that observed in LIL Pb 1381 specimens. Arberia indica (White)

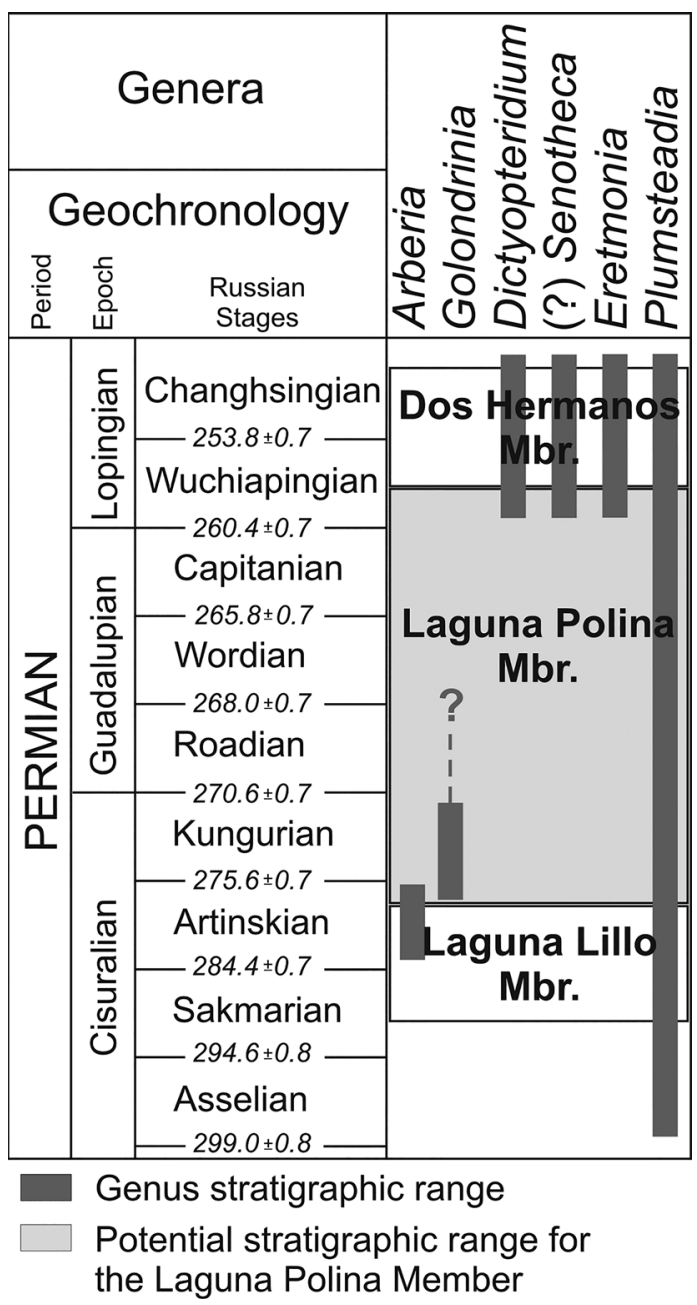

Figure 6. Biostratigraphic ranges of glossopterid ovuliferous genera recovered from the Laguna Polina Member (La Golondrina Formation).

ex Chandra \& Srivastava and A. woolagaensis McLoughlin, 1995 are different from A. madagascariensis in that they bear medium to large seeds sessile or inserted in short stalks (strongly recurved in A. indica) along the margins of the planate axis. These two species are, however, most closely comparable to the polysperms in LIL Pb 1381 in their striate, planate main axis without a prominent apical dichotomy, bearing two lateral rows of fertile branchlets. Last, Arberia hlobanensis Anderson \& Anderson consists of a polysperm with multidimensional branching, distinguishing it from all other Arberia species.

\section{Biostratigraphic implications}

The biostratigraphic scheme for the La Golondrina Formation has remained unmodified since the original proposal by Archangelsky \& Cúneo (1984). According to these authors, the La Golondrina Formation spans the late Cisuralian to the Lopingian. Paleofloristic elements from the lower Laguna Lillo Member were at that time unknown, but recently recovered fossil plants (currently under study), re-confirms an early Permian age for the lower portion of the La Golondrina Formation. On the other hand, the paleoflora 
recovered from the Laguna Polina Member has been studied in detail, as outcrops are widely represented in the basin and the lithology is finer, allowing better preservation of the plants. Thus, the majority of the materials collected to date - including those described here - come from this member. Unfortunately, even after the recent discovery of glossopterid fructifications, such as Dictyopteridium spp., Eretmonia sp. and ?Senotheca sp., considered to be useful biostratigraphic indices (Cariglino, 2013), narrowing the age of each member of the La Golondrina Formation based solely on paleofloristic assemblages has proven inconsistent. Thus, the age of the Laguna Polina Member is still broadly defined, as ranging from the Guadalupian to early Lopingian (Archangelsky \& Cúneo, 1984; Archangelsky et al., 1996a,b; Andreis \& Archangelsky, 1996; Andreis, 2002; Cariglino et al., 2012; Cariglino, 2013) (Figure 6).

The biostratigraphic occurrence of all known Arberiaceae is restricted to the Cisuralian (Artinskian) at all Gondwanan localities (Table 1). In Argentina, Arberia is so far only recorded at Sierra de los Llanos in Paganzo Basin (Arberia cf. A. minasica; Archangelsky \& Arrondo, 1973), and the Tepuel Genoa Basin (Arberia sp.; Gallego et al., 2008). In this context, the presence of Arberia and another new taxon attributed to Arberiaceae in the Laguna Polina Member raises the question about the lower temporal range of this unit. Two possibilities are proposed to explain this dilemma: (i) the stratigraphic range of Arberiaceae should be extended to the middle Permian, or (ii) the lower boundary of the Laguna Polina Member of the La Golondrina Formation should be extended to the upper Cisuralian.

Taking into account that all Arberia and related taxa have been found throughout Gondwana in lower Permian strata, the most parsimonious interpretation is to extend the lower limit of the middle member of the La Golondrina Formation to the upper Cisuralian (Figure 6). Moreover, it is noteworthy that "Arberia allweyensis" Anderson \& Anderson, a poorly preserved singleton, was recovered from the Lawley locality in South Africa, considered Guadalupian in age. However, the recent revision and interpretation of this specimen (see Adendorff, 2005; Shi et al., 2010) places it under Rigbya, a genus commonly used as biostratigraphic index for the Guadalupian-Lopingian.

\section{CONCLUSIONS}

This study recognized two taxa attributed to Arberiaceae from the La Golondrina Formation; one is assigned to a new taxon, Golondrinia archangeslkyi gen. et sp. nov., whereas the other is allocated to Arberia madagascariensis. The general structure of $G$. archangeslkyi gen. et sp. nov. is somewhat similar to that of some Cordaitanthales and Peltaspermales; however, the undeniable presence of fertile branchlets with terminal scale-like structures in all three specimens was diagnostic for its assignation to Arberiaceae. Moreover, the basic morphologic features (i.e. non-dichotomized main axis, fertile branches arrangement) in G. archangelskyi gen. et sp. nov. are considered sufficiently different from the known genera in this family to justify the establishment of a new taxon. The polysperms in LIL $\mathrm{Pb} 1381$ were assignable to $A$. madagascariensis, despite the lack of a clear dichotomization of the main axis.

Relationships within the Glossopteridales have long been debated. In view of the fossil record, most researchers consider Arberia (and allied genera) to bear ancestral characters of glossopterids, which Schopf (1976) and McLoughlin (1993) considered to be derived from a cordaitalean ancestor. Since Arberiaceae fructifications have never been found attached to their vegetative parts, other authors have suggested that Arberia (= Dolianitia) could be the fructification of Cordaites (= Noeggerathiopsis) (Millan, 1967; Bierhorst, 1971; Chandra \& Srivastava, 1981), a view nowadays discarded, as there are no doubts these fructifications belong to Glossopteridales (Rigby, 1972; Anderson \& Anderson, 1985; McLoughlin, 1993; Adendorff, 2005). However, the idea of a close affiliation between both cordaitaleans and glossopterids is still hypothesized (McLoughlin \& Drinnan, 1996). The morphological similarities of Golondrinia archangelskyi gen. et sp. nov. with some fructifications closely allied to cordaitaleans may provide some insights into the relationship between these groups. Better-preserved specimens are needed to evaluate this hypothesis.

This is the first record of Arberiaceae (Glossopteridales) from the La Golondrina Formation. The presence of these fructifications poses a dilemma about the age generally attributed to the formation. With this new evidence, the Laguna Polina Member may extend its range at least to the late Cisuralian (Kungurian?), spanning almost all through the Permian to the early Lopingian, and consequently constraining the lower Laguna Lillo Member to the early Permian (Sakmarian?) (Figure 6). It is clear that a more precise dating methodology other than macrofloral biostratigraphy is needed in the basin, since the floral assemblage, although abundant and diverse, provides inconsistent signals. Until then, the more reliable biostratigraphic indices are without question the fructifications of the various plant groups. In general, in any plant group, the discovery of fertile parts tends to be rarer in comparison with the vegetative parts. This is also the case at the La Golondrina Formation; unfortunately, only one specimen of each fertile taxon described so far has been found, and most commonly, these had preservation that precluded the observation of fine details that would help allocating them at the species or even genus level (see Cariglino, 2013). Despite their rarity, the La Golondrina Formation keeps yielding interesting material within each collecting trip. It is expected that both the number of taxa and specimens will keep increasing, helping to elucidate the diversity and phylogenetic relationships of the different glossopterid families, and improving their stratigraphic significance.

\section{ACKNOWLEDGMENTS}

Special thanks to S. Archangelsky for gently ceding two of the specimens of this study. Many thanks to P.R. Gutiérrez, G. Correa and E. Coturel for field assistance; the Fjell and San 
Juan families for access to the Estancia La Golondrina and Leonardo, respectively; R. Pujana for photographing some of the specimens; and L. Martinez and E. Vera for helpful comments. The manuscript was greatly improved thanks to the corrections in content and the English by S. McLoughlin and an anonymous reviewer. Hand illustration was made by C. Castellano ${ }^{\dagger}$, scientific illustrator at the Fundación Lillo. Funding provided by Préstamo BID PICT 2012-0054 (Agencia Nacional de Promoción Científica y Tecnológica de Argentina).

\section{REFERENCES}

Adendorff, R. 2005. A revision of the ovuliferous fructifications of glossopterids from the Permian of South Africa. University of the Witwatersrand, Ph.D. Thesis (unpublished), $421 \mathrm{p}$.

Adendorff, R.; McLoughlin, S. \& Bamford, M.K. 2002. A new genus of ovuliferous glossopterid fruits from South Africa. Palaeontologia Africana, 38:1-17.

Anderson, J.M. \& Anderson, H.M. 1985. Palaeoflora of southern Africa. Prodromus of South African megafloras: Devonian to Lower Cretaceous. Rotterdam, A.A. Balkema, 423 p.

Andreis, R.R. 2002. Cuenca La Golondrina (depósitos del rift pérmico y evento magmáticos triásicos). In: CONGRESO GEOLÓGICO ARGENTINO, 15, 2002. Relatorio, El Calafate, AGA, p. 71-82.

Andreis, R.R. \& Archangelsky, S. 1996. The Neo-Paleozoic Basins of southern South America. In: M. Moullade \& A.E.M. Nairn (eds.) The Phanerozoic geology of the world, Elsevier, p. 341-650.

Appert, O. 1977. Die Glossopteris flora der Sakoa in südwestMadagaskar. Palaeontographica Abt B, 162:1-50.

Archangelsky, S. 1959. Estudio geológico y paleontológico del Bajo de la Leona (Santa Cruz). Acta Geológica Lilloana, 2:5-133.

Archangelsky, S. 1960. Lycopsida y Sphenopsida del Paleozoico superior de Chubut y Santa Cruz, Patagonia. Acta Geológica Lilloana, 3:21-36.

Archangelsky, S. 1992. Dictyopteridium Feistmantel (fructificaci6n pérmica de Glossopteridales): primer registro argentino. Buenos Aires, Asociación Paleontológica Argentina, p. 19-22 (Publicación Especial 2).

Archangelsky, S. 2006. Dizeugotheca waltonii (Biozona de Intervalo de). In: P.R. Gutiérrez; E.G. Ottone \& S.M. Japas (eds.) Léxico Estratigráfico de la Argentina, Buenos Aires, Asociación Geológica Argentina, p. 108-109 (Didáctica y Complementaria 28).

Archangelsky, S. \& Arrondo, O. 1973. Palaeophytologia Kurtziana III. 10. La tafoflora pérmica de Sierra de los Llanos, provincia de La Rioja. Ameghiniana, 10:201-228.

Archangelsky, S.; Azcuy, C.L.; Césari, S.N.; González, C.R.; Hünicken, M.A.; Mazzoni, A. \& Sabattini, N. 1996b. Correlación y edad de las biozonas. In: S. Archangelsky (ed.) El Sistema Pérmico en la República Argentina y en la República Oriental del Uruguay, Academia Nacional de Ciencias, p. 203-226.

Archangelsky, S. \& Bonetti, M. 1963. Fructificaciones de glossopterídeas del Pérmico del Bajo de la Leona, Provincia de Santa Cruz. Ameghiniana, 3:29-34.

Archangelsky, S. \& Cúneo, N.R. 1984. Zonación del Pérmico continental argentino sobre la base de sus plantas fósiles. In: CONGRESO LATINOAMERICANO DE PALEONTOLOGÍA, 3, 1984. Memorias, México, p. 143-153.
Archangelsky, S.; Jalfin, G.A. \& Cúneo, N.R. 1996a. Cuenca La Golondrina. In: S. Archangelsky (ed.) El Sistema Pérmico en la República Argentina y en la República Oriental del Uruguay, Academia Nacional de Ciencias, p. 93-108.

Arrondo, O.G. 1972. Estudio geológico y paleontológico de la zona de Estancia La Juanita y alrededores, provincia de santa Cruz, Argentina. Revista del Museo de La Plata, 43:1-194.

Bajpai, U. 2001. Some remarks on the glossopterids and stratigraphical distribution of their fructifications during the Permian on Gondwana Supercontinent. The Palaeobotanist, 50:287-293.

Banerjee, M. 1984. Fertile organs of the Glossopteris flora and their possible relationship in the line of evolution. In: SYMPOSIUM ON EVOLUTIONARY BOTANY AND BIOSTRATIGRAPHY, 1, 1979. Proceedings, Calcutta, p. 29-59.

Barreda, V.D. \& Césari, S.N. 1995. Glossopteridales y estructuras reproductivas asociadas en el Flanco Oriental de la Sierra de Los Llanos (Pérmico), Provincia de La Rioja. Argentina. In: CONGRESO ARGENTINO DE PALEONTOLOGÍA Y BIOESTRATIGRAFÍA, 6, 1995. Actas, Trelew, APA, p. 39-46.

Bernardes de Oliveira, M.E.C. 1978. Frutificações de pteridospermófitas eogondvânicas da "Camada Irapuá", Formação Rio Bonito, nos arredores de Criciúma, SC. In: CONGRESSO BRASILEIRO DE GEOLOGIA, 30, 1978. Anais, Recife, p. 986-1001.

Bernardes de Oliveira, M.E.C. \& Carvalho, R. 1981. Frutificações femininas de Glossopterídeas da Formação Rio Bonito, Grupo Tubarão, Estado de Santa Catarina, Brasil. In: CONGRESSO LATINO AMERICANO DE PALEONTOLOGIA, 2, 1981. Anais, Porto Alegre, p. 183-199.

Bernardes de Oliveira, M.E.C.; Ricardi-Branco, F. \& Rösler, O. 2000. As estruturas reprodutivas de Glossopterídeas na sucessão das tafofloras permianas da Bacia do Paraná, Brasil. Revista Universidade Guarulhos, 5:62-68.

Bierhorst, D.W. 1971. Morphology of vascular plants. MacMillan Publications, $560 \mathrm{p}$.

Cariglino, B. 2011. El Pérmico de la Cuenca La Golondrina: Paleobotánica, bioestratigrafía y consideraciones paleoecológicas. Universidad Nacional de La Plata, PhD Thesis, $313 \mathrm{p}$.

Cariglino, B. 2013. Fructification diversity from the La Golondrina Formation (Permian), Santa Cruz Province, Argentina. Geobios, 46:183-193. doi:10.1016/j.geobios.2012.10.017

Cariglino, B.; Coturel, E. \& Gutiérrez, P.R. 2012. The lycophytes of the La Golondrina Formation (Permian), Santa Cruz Province, Argentina: systematic revision, biostratigraphy and palaeoecology. Alcheringa, 36:427-449. doi:10.1080/031155 18.2012.663582

Cariglino, B.; Gutiérrez, P.R. \& Manassero, M. 2009. Plumsteadia pedicellata sp. nov.: a new glossopterid fructification from the La Golondrina Formation (Guadalupian-Lopingian), Santa Cruz Province, Argentina. Review of Palaeobotany and Palynology, 156:329-336. doi:10.1016/j.revpalbo.2009.03.012

Carrizo, M. \& Archangelsky, S. 2013. Kladistamuos golondrinensis nov. gen. et comb., a fertile foliage from the mid to late Permian of Patagonia, Argentina. Review of Palaeobotany and Palynology, 196:1-8. doi:10.1016/j.revpalbo.2013.04.003

Césari, S.N. \& Hünicken, M. 2013. Heterophylly on Cordaites-like foliage from western Gondwana. Review of Palaeobotany and Palynology, 196:9-18. doi:10.1016/j.revpalbo.2013.04.001

Chandra, S. \& Singh, K.J. 1988. A new seed-bearing plant organ from the Kamthi Formation of Orissa, India. Current Science, 57:996-998. 
Chandra, A. \& Srivastava, A.K. 1981. A new species of Arberia from the Lower Gondwana of South Rewa Gondwana Bain, India. The Palaeobotanist, 28-29:40-45.

Delevoryas, T. 1979. Cycadales: a brief note on their history. Cycadales Newsletter, 3:2-6.

Feistmantel, O. 1876. On some fossil plants from the Damuda Series in the Raniganj Coalfield. Journal of the Asiatic Society of Bengal, 45:329-382.

Florin, R. 1951. Evolution in Cordaites and Conifers. Acta Horti Bergiani, 15:285-388.

Gallego, J.; Escapa, I. \& Cúneo, N.R. 2008. El par GlossopterisArberia en la Formación Río Genoa, Pérmico Inferior de Chubut, Argentina. In: SIMPOSIO ARGENTINO DEL PALEOZOICO SUPERIOR, 5, 2008. Abstracts, Buenos Aires, p. 19.

Geng, B. \& Hilton, J. 1999. New coniferophyte ovulate structures from the Early Permian of China. Botanical Journal of the Linnean Society, 129:115-138. doi:10.1111/j.1095-8339.1999. tb00495.x

Grand'Eury, M.F.C. 1877. Mémoire sur la flore Carbonifére du Departement de la Loire et du centre de la France. Mémoires a l'Académie des Sciences de l'Institut de France, 24:1-624.

Gutiérrez, P.R.; Ottone, E.G. \& Japas, S.M. 2006. Léxico Estratigráfico de la Argentina. Buenos Aires, Asociación Geológica Argentina, 368 p. (Didáctica y Complementaria 28).

Holmes, W.B.K. 1974. On some fructifications of the glossopteridales from the Upper Permian of N.S.W. Proceedings of the Linnean Society of New South Wales, 98:131-141.

Iannuzzi, R. 2010. The flora of Early Permian coal measures from the Paraná Basin in Brazil: a review. International Journal of Coal Geology, 83:229-247. doi:10.1016/j.coal.2010.05.009

Ignatiev, I.A. \& Meyen, S.V. 1989. Suchoviella gen. nov. from the Permian of Angaraland and a review of the systematics of Cordaitanthales. Review of Palaeobotany and Palynology, 57:313-339. doi:10.1016/0034-6667(89)90028-6

Jalfin, G.A. 1987. Estratigrafia y paleogeografia de las Formaciones La Golondrina y La Juanita, Pérmico de la provincia de Santa Cruz y su relación con rocas de edad similar en las Islas Malvinas. Universidad Nacional de Tucumán, Ph.D. Thesis (unpublished), $219 \mathrm{p}$.

Jalfin, G.A. 1990. Grupo Tres Cerros. Denominación formal para las sedimentitas neopaleozoicas que conforman el relleno de la Cuenca La Golondrina, provincia de Santa Cruz, Argentina. In: Annual Meeting Working Group, Buenos Aires, IGCP, p. 36-39 (Project 211).

Kerp, J.H.F. 1988. Aspects of Permian palaeobotany and palynology. $\mathrm{X}$. The west- and central European species of the genus Autunia Krasser emend. Kerp (Peltaspermaceae) and the formgenus Rhachiphyllum Kerp (Callipterid foliage). Review of Palaeobotany and Palynology, 54:249-360. doi:10.1016/00346667(88)90017-6

Lacey, W.S. \& Huard-Moine, D. 1966. Karroo Floras of Rhodesia and Malawi. Part 2. The Glossopteris Flora in the Wankie District in Southern Rhodesia. In: SYMPOSIUM ON FLORISTICS AND STRATIGRAPHY OF GONDWANALAND, 1, 1966. Proceedings, Lucknow, p. 13-25.

Lesquereaux, L. 1880. On a branch of Cordaites, bearing fruit. Proceedings of the American Philosophical Society of Philadelphia, 18:222-223.

Maithy, P.K. 1970. Studies in the Glossopteris flora of India - 39. On some new plant fossils from the Karharbari Beds, Giridih Coalfield, India. The Palaeobotanist, 18:167-172.
McLoughlin, S. 1990a. Some Permian glossopterid fructifications and leaves from the Bowen Basin, Queensland, Australia. Review of Palaeobotany and Palynology, 62:11-40. doi:10.1016/00346667(90)90015-B

McLoughlin, S. 1990b. Late Permian glossopterid fructifications from the Bowen and Sydney Basins, eastern Australia. Geobios, 23:283-297. doi:10.1016/0016-6995(90)80002-W

McLoughlin, S. 1993. Glossopterid megafossils in Permian Gondwanic non-marine biostratigraphy. In: R.H. Findley; M.R. Banks; J.J. Veevers \& R. Unrug (eds.) Gondwana Eight: assembly, evolution and dispersal, Brookfield, p. 253-264.

McLoughlin, S. 1995. New records of Bergiopteris and glossopterid fructifications from the Permian of Western Australia and Queensland. Alcheringa, 19:175-192. doi:10.1080/03115519508619505

McLoughlin, S. 2012a. Two new Senotheca (Glossopteridales) species from the Sydney Basin, Australia, and a review of the genus. Review of Palaeobotany and Palynology, 171:140-151. doi:10.1016/j.revpalbo.2011.12.004

McLoughlin, S. 2012b. Nogoa nom. nov., a replacement name for Cometia McLoughlin. Alcheringa, 36:279-281. doi:10.1080/0 3115518.2012.632671

McLoughlin, S. \& Drinnan, A.N. 1996. Anatomically preserved Noeggerathiopsis leaves from east Antarctica. Review of Palaeobotany and Palynology, 92:207-227. doi:10.1016/00346667(96)00134-0

Menéndez, C.A. 1962. Hallazgo de una fructificación en la flora de Glossopteris de la Provincia de Buenos Aires (Lanceolatus bonaerensis sp.nov.). Consideraciones sobre la nomenclatura de fructificaciones de Glossopteris. Ameghiniana, 2:175-182.

Meyen, S.V. 1984. Basic features of Gymnosperm systematics and phylogeny as evidenced by the fossil record. The Botanical Review, 50:1-111. doi:10.1007/BF02874305

Millan, J.H. 1967. Novas frutificações na flora Glossopteris do Gonduana Inferior do Brasil. Dolianitia gen. nov. Rio de Janeiro, Departamento Nacional de Produção Mineral, Divisão de Geologia e Mineralogia, p. 1-19 (Notas Preliminares e Estudos 140).

Naugolnykh, S.V. \& Oskolski, A.A. 2010. An advanced peltasperm Permoxylocarpus trojanus Naug. from the Lower Permian of the Urals (Russia): an ancient case of entomophily in gymnosperms? Wulfenia, 17:29-43.

Pant, D.D. 1982. The Lower Gondwana gymnosperms and their relationships. Review of Palaeobotany and Palynology, 37:5570. doi:10.1016/0034-6667(82)90037-9

Pant, D.D. \& Nautiyal, D.D. 1965. Seed bearing Ottokarialike fructification from India. Nature, 207:623-624. doi:10.1038/207623a0

Panza, J.L. 1994. Hoja Geológica 4966-I/II Bahía Laura, escala 1:250000 (Santa Cruz). Buenos Aires, Dirección Nacional del Servicio Geológico, 83 p. (Boletín 214).

Prevec, R. 2011. A structural re-interpretation and revision of the type material of the glossopterid ovuliferous fructification Scutum from South Africa. Palaeontologia Africana, 46:1-19.

Prevec, R.; McLoughlin, S. \& Bamford, M.K. 2008. Novel double wing morphology revealed in a South African ovuliferous glossopterid fructification: Bifariala intermittens (Plumstead 1958) comb. nov. Review of Palaeobotany and Palynology, 150:22-36. doi:10.1016/j.revpalbo.2008.01.001

Rigby, J.F. 1972. On Arberia White, and some related lower Gondwana female fructifications. Palaeontology, 15:108-120. 
Rigby, J.F. 1978. Permian glossopterid and other cycadopsid fructifications from Queensland. Brisbane, Geological Survey of Queensland, p. 3-21 (Publication 367).

Rösler, O.; Bernardes de Oliveira, M.E.C.; Rohn, R. \& Peñaloza, A. 1994. Frutificação associada a Glossopteris na Formação Rio do Rasto, Estado de Paraná. In: REUNIÃODE PALEOBOTÂNICOS E PALINÓlOGOS, 8, 1994. Resumos, São Paulo, p. 67.

Ryberg, P.; Taylor, E.L. \& Taylor, T.N. 2012. Antarctic glossopterid diversity on a local scale: The presence of multiple megasporophyll genera, Upper Permian, Mt. Achenar, Transantarctic Mountains, Antarctica. American Journal of Botany, 99:1531-1540. doi:10.3732/ajb.1200142

Schopf, J.M. 1976. Morphologic interpretation of fertile structures in glossopterid gymnosperms. Review of Palaeobotany and Palynology, 21:25-64. doi:10.1016/0034-6667(76)90021-X

Shi, G.R.; Waterhouse, J.B. \& McLoughlin, S. 2010. The Lopingian of Australasia: a review of biostratigraphy, correlations, palaeogeography and palaeobiogeography. Geological Journal, 45:230-263. doi:10.1002/gj.1213

Srivastava, A.K. \& Agnihotri, D. 2013. Coal seam correlation of an Indian Gondwana coalfield: a palaeobotanical perspective. International Journal of Coal Geology, 113:88-96. doi:10.1016/j. coal.2012.06.009
Surange, K.R. \& Chandra, S. 1975. Morphology of the gymnospermous fructifications of the Glossopteris flora and their relationships. Palaeontographica AbtB, 149:153-180.

Surange, K.R. \& Lele, K.M. 1956. Studies in the Glossopteris flora of India - 6. Plant fossils from Talchir Beds of South Rewa Gondwana Basin. The Palaeobotanist, 5:82-90.

Taylor, T.N.; Taylor, E.L. \& Krings, M. 2009. Paleobotany - The biology and evolution of fossil plants. $2^{\text {nd }}$ ed. New York, Academic Press, $1230 \mathrm{p}$.

Tewari, R.; Pandita, S.K.; Agnihotri, D.; Pillai, S.S.K. \& Bernardesde-Oliveira, M.E.C. 2012. An Early Permian Glossopteris flora from the Umrer Coalfield, Wardha Basin, Maharashtra, India. Alcheringa, 36:355-371. doi:10.1080/03115518.2012.648416

Wang, Z.-Q. 1997. Permian Supaia fronds and an associated Autunia fructification from Shanxi, China. Palaeontology, 40:245-277.

Received in August, 2014; accepted in October, 2015. 